\title{
ORTHOPAEDIC TELEMEDICINE SERVICES DURING THE CURRENT NOVEL CORONAVIRUS PANDEMIC
}

\section{SERVIÇO DE TELEMEDICINA EM ORTOPEDIA DURANTE A ATUAL PANDEMIA DO CORONAVÍRUS}

\author{
Paulo Henrique Schmidt Lara ${ }^{1}$ (i), Carolinne Nascimento de Oliveira ${ }^{2}$ (D), Vinícius Tiburtino Chaves Oliveira ${ }^{2}$ (1),

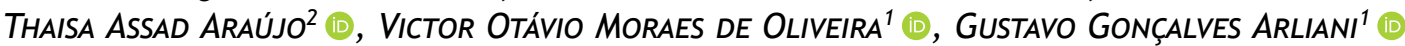

1. Prevent Senior, Orthopaedics and Traumatology Group, São Paulo, São Paulo, Brazil.

2. Prevent Senior, Orthopaedics and Traumatology Residents Group, São Paulo, São Paulo, Brazil.

\begin{abstract}
Introduction: To evaluate the use of telemedicine by physicians specializing in orthopaedics and traumatology at the authors' institution, and to assess the rates of satisfaction and resolution for this type of care. The current global coronavirus disease 2019 (COVID-19) pandemic has resulted in the expansion of telemedicine services. However, quality measures and barriers for physicians dealing with the rapid increase in patients have not been well described. Materials and Methods: This study included 255 patients with orthopaedic complaints. Between 24 and 48 hours after the appointment, independent physicians, who did not participate in the initial appointment, contacted one another to assess the degree of satisfaction with the appointment, and whether there was a solution to the orthopaedic complaint. Results: There was a need for referral for face-to-face consultation in only $13.8 \%$ of cases. When asked about the probability of recommending telemedicine to a friend/family member, the answer was $90.3 \%$. The satisfaction rate with the service was $91.1 \%$ and $93.69 \%$ of patients would return for a telemedicine consultation. Telemedicine consultations solved the problem in $82.74 \%$ of cases. Conclusions: Telemedicine care in orthopaedics proved to be a service modality with a high rate of satisfaction among the patients evaluated. Level of evidence III, Retrospective cohort study.
\end{abstract}

Keywords: Orthopedics. Pandemics. Telemedicine.

\begin{abstract}
RESUMO
Introdução: O estudo avaliou o uso da telemedicina por especialistas em ortopedia e traumatologia da instituição dos autores e avaliou os indices de satisfação e resolução desse tipo de atendimento. A atual pandemia causada pelo coronavírus 2019 (COVID-19) resultou na expansão dos serviços de telemedicina. Contudo, as medidas de qualidade e barreiras para médicos que lidam com o rápido aumento não foram bem descritas. Material e Método: Este estudo incluiu 255 pacientes com queixas ortopédicas. Entre 24 e 48 horas depois da consulta, médicos independentes, que não participaram da primeira consulta, entraram em contato para avaliar o grau de satisfação com o atendimento e se houve solução da queixa ortopédica. Resultados: Houve necessidade de encaminhamento para consultas presenciais em apenas 13,8\% dos casos. Quando questionados sobre a probabilidade de recomendar a telemedicina para um amigo/familiar, a resposta dos participantes foi 90,3\%. A taxa de satisfação com o serviço foi de 91,1\% e 93,6\% de pacientes que retornariam para consulta por telemedicina. As consultas de telemedicina resolveram o problema em $82,74 \%$ dos casos. Conclusões: O atendimento por telemedicina em ortopedia mostrou ser uma modalidade de serviço com alto índice de satisfação entre os pacientes avaliados. Nível de evidência III, Estudo de coorte retrospectivo.
\end{abstract}

Descritores: Ortopedia. Pandemia. Telemedicina.

Citation: Lara PHS, Oliveira CN, Oliveira VTC, Araújo TA, Oliveira VOM, Arliani GG. Orthopaedic telemedicine services during the current novel coronavirus pandemic. Acta Ortop Bras. [online]. 2022;30(1): Page 1 of 3. Available from URL: http://www.scielo.br/aob.

\section{INTRODUCTION}

Shortly after the outbreak and rapid spread of coronavirus disease 2019 (COVID-19), the World Health Organization declared it a pandemic on March 11, 20201. Governments around the world are quickly realising the impact of COVID-19 on healthcare services and the economy. Amid reports regarding the spread of the causative agent-severe acute respiratory syndrome coronavirus 2 (SARS-CoV2)-there is also recognition that online tools, such as telemedicine, can play a critical role in the global response to this crisis.
Telemedicine is ideal for the management of communicable diseases. A key factor in delaying the transmission of a virus is "social distancing" 2-5, which is aimed at decreasing interpersonal contact. For patients with COVID-19, or those concerned about the possibility of being infected with SARS-CoV-2, telemedicine can help with remote assessment (screening) and the provision of initial care. For individuals not infected with SARS-CoV-2, especially those most at risk for being affected (e.g., elderly individuals with co-morbid or pre-existing medical conditions), telemedicine can

All authors declare no potential conflict of interest related to this article.

The study was conducted at the Instituto de Ortopedia Prevent Senior.

Correspondence: Paulo Henrique Schmidt Lara. Rua José Oscar de Abreu Sampaio, 368, Jardim Anália Franco, São Paulo, SP, Brasil. 03337-020. phslara@gmail.com 
provide convenient and remote access to routine care without the risk for exposure to hospital environments or waiting rooms in physicians' offices and outpatient clinics ${ }^{6-10}$.

However, for telemedicine to be effective during the current COVID-19 pandemic and similar future events, we must ensure that the tool is properly integrated into existing health services. The purpose of this study was to evaluate the use of telemedicine in orthopaedics and traumatology consultations at our institution, and to assess the rate of satisfaction with and resolvability in this type of service.

\section{METHODOLOGY}

This prospective, observational study included 300 patients with orthopaedic complaints, who were treated by physicians specialising in orthopaedics and trauma from the authors' institution, using the institution's telemedicine platform. After initial consultation, the physicians completed a questionnaire addressing items such as diagnostic hypothesis, examinations requested, and proposed treatment, whether there was a need for referral for face-to-face consultation, and total consultation time. In the period from 24 to $48 \mathrm{~h}$ after the appointment, independent physicians, who did not participate in the initial appointment, contacted one another to assess the degree of satisfaction with the appointment and completed a questionnaire with questions including: age; what is the probability of indicating the telemedicine for a friend/family member; how satisfied you were with the service; if you would have a telemedicine consultation again; and if the consultation solved your problem. When the physicians get in touch to evaluate the care, the consent form is sent by e-mail or cell phone message, and if the patient agrees to participate, he/she will accept by e-mail or cell phone.

\section{Inclusion criteria}

Patients undergoing orthopeadic consultation using telemedicine during the study period.

\section{Exclusion criteria}

Patients who did not wish to or were not contacted for evaluation after care.

\section{RESULTS}

Of the 300 patients initially recruited, 255 were contacted. The mean age of the patients was 64.75 years (range, 15-95 years). The average consultation time was $22.65 \mathrm{~min}$ (range, 4-45 min). Summaries of the diagnostic hypotheses, requested examinations, and proposed treatment are presented in Tables 1 to 3, respectively.

Table 1. Distribution of diagnostic hypotheses.

\begin{tabular}{c|c}
\hline Diagnostic hypotheses & \\
\hline Backacke & $76,4 \%$ \\
\hline Rotator Cuff Syndrome & $49,01 \%$ \\
\hline Gonarthrosis & $37,2 \%$ \\
\hline Coxarthrosis & $36,8 \%$ \\
\hline Neck pain & $22,74 \%$ \\
\hline Lumbociatalgia & $22,35 \%$ \\
\hline Carpal tunnel syndrome & $11,3 \%$ \\
\hline Trigger finger & $9,8 \%$ \\
\hline Back pain & $9,01 \%$ \\
\hline Epicondylitis & $6,27 \%$ \\
\hline Gluteal tendinopathy & $5,88 \%$ \\
\hline Plantar fasciitis & $5,09 \%$ \\
\hline Remaining & $<5 \%$ \\
\hline
\end{tabular}

\begin{tabular}{c|c}
\hline \multicolumn{2}{|l}{ Table 2. Distribution of requested exams. } \\
\hline Requested exams & \\
\hline None & $43,89 \%$ \\
\hline Xrays & $18,77 \%$ \\
\hline Ultrasound & $10,32 \%$ \\
\hline Nuclear magnetic resonance & $3,82 \%$ \\
\hline Computed tomography & $2,88 \%$ \\
\hline Eletroneuromiography & $0,93 \%$ \\
\hline
\end{tabular}

\begin{tabular}{l|l}
$\begin{array}{c}\text { Table 3. Distribution of treatments performed. } \\
\text { Treatment }\end{array}$ \\
\hline Analgesic & $87 \%$ \\
\hline Physiotherapy & $75 \%$ \\
\hline Opioids & $66 \%$ \\
\hline Anti-inflamatories & $65 \%$ \\
\hline Acupuncture & $51 \%$ \\
\hline Chondroprotectors & $25 \%$ \\
\hline Orientation & $20 \%$ \\
\hline Shockwave therapy & $3,5 \%$ \\
\hline
\end{tabular}

There was a need for face-to-face referral consultation in only $13.8 \%$ of cases. When asked about the probability of recommending telemedicine to a friend/family member, the response was "yes" in $90.3 \%$, and the satisfaction rate with the service was $91.1 \%$. A total of $93.69 \%$ of patients would return for a telemedicine consultation. Of the 15 patients who did not return, the reasons were as follows: they would not participate in telemedicine consultation in the orthopaedics specialty $(n=7)$; only if there was no face-to-face consultation ( $n=5)$; only in cases of return $(n=2)$; and because physicians requested too many examinations in this type of care $(n=1)$. The consultation performed by telemedicine solved the problem in $82.74 \%$ of cases.

\section{DISCUSSION}

Due to the challenges imposed by the current coronavirus pandemic (i.e., COVID-19), we observed an increase in the use of telemedicine in orthopaedics. Current studies have reported that satisfaction rates with the use of telemedicine are comparable to those of face-to-face consultations, and patients who experience virtual consultation are more likely to seek this type of care in the future ${ }^{11-17}$. In our study, we obtained similar results, with a high rate of satisfaction, as well as a high percentage of patients who would return to use this type of care.

Buvik et al. ${ }^{11}$ conducted a randomised clinical trial involving 389 patients, of whom $86 \%$ preferred consultation by telemedicine in orthopaedics over personal consultation, and 99\% indicated that they were satisfied or very satisfied with consultation by telephone. Sinha et al. ${ }^{16}$ conducted a non-randomised study in which they compared paediatric follow-up after fracture performed by telemedicine and in person. Although the satisfaction levels of the two groups were similar, telemedicine reduced the costs and time associated with consultation. In addition, only 8 of the 101 patients who were treated with telemedicine preferred the next consultation to be in person. Bertani et al. ${ }^{17}$ performed a prospective evaluation of paediatric orthopaedic consultations between 2009 and 2011, and found that consultation by telemedicine resolved $90 \%$ of diagnostic doubts, although the clinical outcome was reported to be "good" or "very good" in only $81 \%$ of patients. Haukipuro et al. ${ }^{18}$ conducted a randomised clinical trial of orthopaedic services and found that the level of patient satisfaction was similar in the telemedicine $(n=76)$ and face-to-face $(n=69)$ consultation groups. 
In a study by Hurley et $a .^{19}, 268$ orthopaedists were interviewed about the use of telemedicine, in which $84.8 \%$ of surgeons were currently using telemedicine, but only $20.5 \%$ of surgeons used it before the COVID-19 pandemic. The satisfaction rate with the use of telemedicine ranged from $20.9 \%$ to $70.3 \%$. Among those who used telemedicine, $75 \%$ used it for new patients, $86.6 \%$ for routine monitoring, and $80.8 \%$ for postoperative patients.

Orthopaedists were more easily able to perform the physical examination in patients who were already accompanied or who were in the postoperative period than in those who were undergoing the first consultation. Thus, they reported that after the COVID-19 pandemic, they tended to maintain telemedicine in these patients. A very important point is which patients experience the greatest benefit from using telemedicine. In our study, 15 patients reported that they would not return to consultations by telemedicine in orthopaedics. Of these, $46 \%$ reported that they would not participate in the orthopaedics specialty, $33.3 \%$ only if there was no face-to-face consultation, $13.3 \%$ only in return visits, and $0.06 \%$ stated that they would not participate the telemedicine consultation again because physicians ordered too many exams.

To our knowledge, this was the first study to investigate the use of telemedicine in orthopaedics in our country to enable the assessment of the perception(s) of patients who are subjected to this type of care. A limitation of this study was that there was no comparison with face-to-face consultations, not only to compare satisfaction and resolution rates, but also cost(s). An important question is whether orthopaedists actually request a greater number of tests in telemedicine services, given the limitations to physical examinations that may exist. Because our study was performed during the COVID-19 pandemic, we did not perform a comparison with the face-to-face consultation; however, we aim to do so in the near future. In addition, due to the characteristics of the beneficiaries of the health plan in our study, the average age was high. Among elderly patients, it may be more difficult to use telemedicine. However, there was a high rate of satisfaction among the patients who participated in our study, suggesting that advanced age is not necessarily a limiting factor for the use of this type of care.

\section{CONCLUSION}

Telemedicine care in orthopaedics proved to be a service modality with a high rate of satisfaction among the patients evaluated, and a high proportion returning to this type of care. Telemedicine demonstrated a high rate of resolvability without the need for referral for face-to-face consultation.

AUTHORS' CONTRIBUTION: Each author helped substantially to the development of this study. PHSL: Data analysis, critical review, study text and final approval. CNO, VTCO and TAA: Data acquisition. VOMO and GGA: Critical review and final approval.

\section{REFERENCES}

1. World Health Organization WHO Director-General's opening remarks at the media briefing on COVID-19 11 March 2020. World Health Organization. Accessed 15 Jun 2020. Available at: https://www.who.int/dg/speeches/detail/who-director-general-s-opening-remarks-at-the-media-brief ing-on-covid-19-11-march-2020.

2. Duffy S, Lee TH. In-person health care as option B. N Engl J Med. 2018; 378:104-6.

3. Joshi AU, Randolph FT, Chang AM, Slovis BH, Rising KL, Sabonjian M, et al. Impact of emergency department tele-intake on left without being seen and throughput metrics. Acad Emerg Med. 2020;27:139-47.

4. Lurie N, Carr BG. The role of telehealth in the medical response to disasters. JAMA Intern Med. 2018;178:745-6.

5. Public Health England Coronavirus (COVID-19): What is social distancing? UK Health Security Agency. Accessed 15 Jun 2020. Available at: https://ukhsa. blog.gov.uk/2020/03/04/coronavirus-covid-19-what-is-social-distancing/ (LINK CORRIGIDO)

6. Adler-Milstein J, Kvedar J, Bates DW. Telehealth among US hospitals: several factors, including state reimbursement and licensure policies, influence adoption. Health Aff (Millwood). 2014;33(2):207-15.

7. Orlando JF, Beard M, Kumar S. Systematic review of patient and caregivers satisfaction with telehealth videoconferencing as a mode of service delivery in managing patients' health. PLoS One. 2019;14(8):e0221848.

8. Scott Kruse C, Karem P, Shifflett K, Vegi L, Ravi K, Brooks M. Evaluating barriers to adopting telemedicine worldwide: A systematic review. J Telemed Telecare. 2018;24(1):4-12.

9. Tenforde AS, laccarino MA, Borgstrom HD, Hefner JE, Silver J, Ahmed M, et al. Feasibility and High Quality Measured in the Rapid Expansion of Telemedicine During COVID-19 for Sports and Musculoskeletal Medicine Practice. PM R. 2020;12(9):926-932.
10. Verduzco-Gutierrez M, Bean AC, Tenforde AS, Tapia RN, Silver JK. How to Conduct an Outpatient Telemedicine Rehabilitation or Prehabilitation Visit. PM R. 2020;12(7):714-720.

11. Buvik A, Bugge E, Knutsen G, Sma brekke A, Wilsgaard T. Patient reported outcomes with remote orthopaedic consultations by telemedicine: a randomised controlled trial. J Telemed Telecare. 2019;25(8):451-9.

12. Eriksson L, Lindström B, Ekenberg L. Patients' experiences of telerehabilitation at home after shoulder joint replacement. J Telemed Telecare. 2011;17(1):25-30.

13. Gilbert AW, Jaggi A, May CR. What is the patient acceptability of real time 1 : 1 videoconferencing in an orthopaedics setting? A systematic review Physiotherapy. 2018;104(2):178-86.

14. Harrison R, Macfarlane A, Murray E, Wallace P. Patients' perceptions of joint teleconsultations: a qualitative evaluation. Health Expect. 2006;9(1):81-90. 35.

15. Kairy D, Tousignant M, Leclerc N, Côté AM, Levasseur M, Researchers TT. The patient's perspective of in-home telerehabilitation physiotherapy services following total knee arthroplasty. Int J Environ Res Public Health. 2013;30;10(9): 3998-4011.

16. Sinha N, Cornell M, Wheatley B, Munley N, Seeley M. Looking through a different lens: patient satisfaction with telemedicine in delivering pediatric fracture care. J Am Acad Orthop Surg Glob Res Rev. 2019;3(9):e100.

17. Bertani A, Launay F, Candoni P, Mathieu L, Rongieras F, Chauvin F. Teleconsultation in paediatric orthopaedics in Djibouti: evaluation of response performance. Orthop Traumatol Surg Res. 2021;98(7):803-7.

18. Haukipuro K, Ohinmaa A, Winblad I, Linden T, Vuolio S. The feasibility of telemedicine for orthopaedic outpatient clinics-a randomized controlled trial. J Telemed Telecare. 2020;6(4):193-8.

19. Hurley ET, Haskel JD, Bloom DA, Gonzalez-Lomas G, Jazrawi LM, Bosco JA, III, et al. The Use and Acceptance of Telemedicine in Orthopedic Surgery During the COVID-19 Pandemic. Telemed J E Health. 2021;27(6):657-662. 